\title{
Remote Sensing and GIS Application for Shoreline Change Measurement in South East Coastal region of Tamil Nadu, India
}

\author{
Gurugnanam B.
}

\begin{abstract}
This Present study attempt to highlights the ability of Geospatial Technology to explore the changes in the coastal tract. The study also find out some major changes in terms of erosion and deposition of 33 Years (1972 to 2013) through the toposheet and satellite datas. Arc GIS software used to address the amount of changes in the study area. The satellite datas includes Landsat, IRS P6 LISS 4M, TM and ETM has been used to bring out the shorelines. Changes were noticed from the imageries and a comparative study was undergone using GIS. The shoreline taken a length of $9.3 \mathrm{~km}$ and it buffered $3 \mathrm{~km}$ which contains $19.1 \mathrm{~km}^{2}$ of land and $22.62 \mathrm{~km}^{2}$ of sea in part of Cuddalore district, Tamil nadu. For the given study area base map (Fig. 1) expose details of coastal plain. Along with that Digital Shoreline Analysis System the tool provided by USGS can Work with GIS Platform help to identify and classify the rate of shore changes in terms of High or Low Erosion and Accretion based on Linear Regression Rate (LRR), It was a statistical approach in software carried out by fitting least square regression line to all shoreline points for a particular transect. The study area is under erosion with an average of $-2.63 \mathrm{~m} / \mathrm{year}$.
\end{abstract}

Keywords: Shoreline, Accretion, Erosion, Arc GIS, LRR, Cuddalore.

\section{INTRODUCTION}

Coastal region is one of the important part in the earth surface, where always occur various changes [Majed Bouchahma et al.2013], The Tamilnadu coastal region is one which affected by hazardous impact of 2004 Sumatra Tsunami, the region is low lying and gentle slope that tends erosion and make it a vulnerable (Saxena.s et al. 2012). Erosion and Accretion are the common changes that would happen on the coastal regions caused either by natural force or Manmade. (Usha et al. 2015). As a region affected by this hazardous wave, erosion have got increased compared to previous years. Abundance of resources in sea makes peoples to settle in near coastal, as a result, artificial constructions also increase. After Tsunami, the region is characterized by dominated erosion than deposition (kumaravel et al., 2013). This study access the shoreline changes in part of cuddalore old town, Sattikkupam, Kudikkadu, Sangilikuppam, Nachchikkadu, parts of Cuddalore District.

\section{A. Study Area}

The study area shows in lies in the coastal belts of Cuddalore District, Tamil Nadu, India.

Revised Manuscript Received on February 05, 2020.

* Correspondence Author

Gurugnanam B.*, Centre for Applied Geology, The Gandhigram Rural Institute - Deemed to be University, Dindigul, Tamil Nadu, India. Email: gurugis4u@gmail.com.

(C) The Authors. Published by Blue Eyes Intelligence Engineering and Sciences Publication (BEIESP). This is an open access article under the CC BY-NC-ND license (http://creativecommons.org/licenses/by-nc-nd/4.0/)
It is bounded on the north by Pondicherry Union Territory, south by cuddalore district, east by Bay of Bengal and west by Panruti and Virudhachalam Taluks of Cuddalore district. The Study

located between $11^{\circ} 39^{\prime} 11^{\prime \prime}$ and $11^{\circ} 42^{\prime} 24^{\prime \prime} \mathrm{N}$ latitudes, and $79^{\circ} 44^{\prime} 24^{\prime \prime}$ and $79^{\circ} 48^{\prime} 35^{\prime \prime}$ E longitudes. The total length of shoreline taken as $9.3 \mathrm{~km}$

\section{MATERIALS AND METHODS}

Geospatial Technology have a vital role to analyses and monitor the morphological changes on earth surface. [Kwarteng et al.2009]. For the present study base map is prepared from the Survey of India Toposheet (SOI) map and to analyze the shoreline changes Multi-spectral and MultiTemporal satellite data of Landsat 1991, 1999, resourcesat 2008 and IRS P6, LISS 4 MX, Landsat TM and ETM were used for the study. The input satellite imageries from the various data sources, had gone through Image preprocessing includes the detection and restoration of band lines were processed using Image processing software.

\section{A. Shoreline Extraction}

Shoreline is an active coastal feature between the land and sea (Anirban et al.2012). In the coastal erosional and depositional studies, the shoreline only can expose the changes in the coast. The satellite imageries with false color composition helps to identify and extract the shoreline [Mageswaran et al. 2015]. The variation in infrared portion of electromagnetic spectrum shows low reflectance in water and high reflectance on sand [Ateeth Shetty et al.2015; Balasaraswathi and Srinivasalu, 2016]. Arc GIS Software used to delineate the shoreline. Shorelines extracted from Multi-year satellite imageries was the recent trend which help for identify and assess the changes (Lee and Jurkevich, 1990). The net shoreline changes for the time span of 19711991, 1991-2000, 2000-2006, 2006-2008 as well 2008-09, 2009-2011 and 2011-2013 have got delineate through the same way. Accordingly, Net accretion and erosion rate were calculated for the Coastal region namely, Sattikkupam, Kudikkadu, Sangilikuppam, Nachchikkadu, parts of Cuddalore District. Using shoreline from the year (1971 2013).

Published By:

Blue Eyes Intelligence Engineering 


\section{B. Shoreline change analysis}

A comparative study has done initially using the Multiyear shorelines to identify the amount of changes and The Digital Shoreline Analysis System (DSAS) is an extension Software provide by USGS used to compute rate-of-change statistics for a time series of shoreline vector data. It calculates the horizontal displacement [Sheeja P.S et al.2016] [ Bouchahma et al. 2012]. For the study 72 transects were plotted with a gap of $100 \mathrm{~m}$ interval from the baseline towards shore. LRR of change statistics is commonly used for this statistical calculation. Shoreline movement and estimating rates of change calculations are estimated by this method [Ram Anand et al. 2016]. The values show in negative which means entire study area was under erosion with an average rate of $-2.63 \mathrm{~m} /$ year. The comparison of minimum and maximum values of LRR shows relatively high erosion along the Bay of Bengal coast. it confirms the coastline have high erosion along the villages Sattikkupam, Kudikkadu, Sangilikuppam, Nachchikkadu, parts of Cuddalore District Figure 10.

Table: 1 List of spatial data products

\begin{tabular}{|c|c|c|c|c|}
\hline $\begin{array}{c}\text { Name of } \\
\text { the } \\
\text { Satellite }\end{array}$ & Landsat & Landsat & IRS & IRS P6 \\
\hline $\begin{array}{c}\text { Date of } \\
\text { Acquisition }\end{array}$ & $25-08-91$ & $\begin{array}{c}2000 / 10 / 28 \\
2006 / 10 / 12\end{array}$ & $\begin{array}{c}\text { 2008/02/06, } \\
2009 / 12 / 06\end{array}$ & $\begin{array}{c}24-05- \\
13\end{array}$ \\
\hline Sensor & $\begin{array}{c}\text { TM } \\
\text { USGS }\end{array}$ & $\begin{array}{l}\text { ETM+ } \\
\text { USGS }\end{array}$ & LISS III & LISS IV \\
\hline $\begin{array}{l}\text { Path \& } \\
\text { Row No }\end{array}$ & $142 / 052$ & $142 / 052$ & $102-65$ & $102-65$ \\
\hline
\end{tabular}

\section{RESULTS AND DISCUSSION}

\section{A. Erosion and Accretion Identification}

The study deals with the shoreline changes in part of cuddalore stretch, the coastline 9.3. km which having a buffered area of $19.89 \mathrm{~km} 2$ toward land and $21.32 \mathrm{~km} 2$ to sea. Topographical maps and satellite imageries provide the shorelines of each year for the comparative study. This work initiates with finding the amount of changes of shore by overlying with multiple year shorelines acquired from 19712013 satellite data. fig (3). Between 1971-1991 map shows only accretion in whole study area the cuddalore town, Kudikkadu Sangilikuppam to Nachchikkadu, accreded an area of $1.53 \mathrm{~km} 2$ from the 1971 shoreline, the changes are graphically represented in (Fig. 2a). The same procedure used to access the changes up to 2013. (Fig.2b) Shows the changes from the year 1991-2000 and there shows an accreded area of $0.26 \mathrm{~km} 2$ along the coast but no erosional changes throughout those years. In between 2000 to 2006 the

rate of Changes initiated in forms of minor erosion with an area of $0.7 \mathrm{~km} 2$ and accreted an area of $0.01 \mathrm{~km} 2 \mathrm{in}$ the specified year (Fig 2c). While compared with the previous year the rate of accretion is less and there it shows erosion in the surrounding part of cuddalore old town, sattikkupaam,

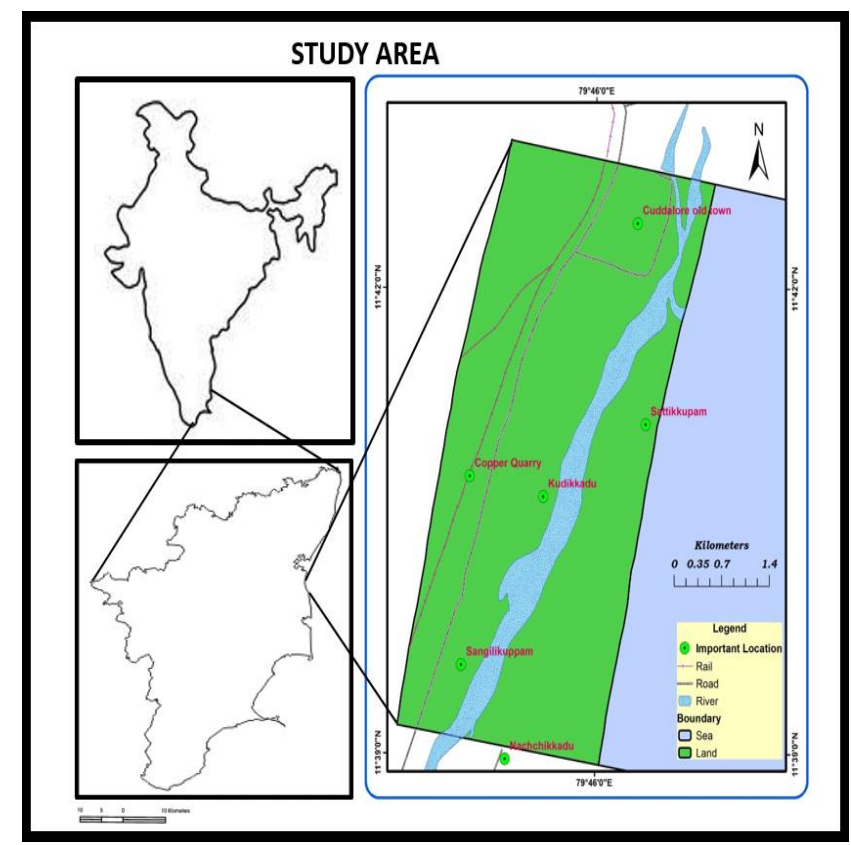

Figures 1: Study Area

Kudikkadu, coast. (Fig 2d) shows the drastic variation in shoreline in form of erosion between 2006 to 2008 an area of $0.35 \mathrm{~km} 2$ have got eroded. The (Fig 2e) highlights accretional changes during the year 2008 and 2009 an area of $0.49 \mathrm{~km} 2$ got accreded whole over the coast and no erosion noticed during this period...During 2009-2011 , $0.06 \mathrm{~km} 2$ area accreded in northern part of cuddalore old town and also $0.06 \mathrm{~km} 2$ of area was eroded in the southern area near to Sattikupam village it was graphically shown in (Fig.2f). From 2011 to 2013 data the changes noticed the area have no accretion but an erosion of $0.67 \mathrm{~km} 2$ occurred in the coast cuddalore old town, sattikkupam, Kudikkadu and Nachchikkadu. (Fig .2g).

\section{B. Linear Regression Rate}

For the villages, Sattikkupam, Kudikkadu, Sangilikuppam, Nachchikkadu, parts of Cuddalore District coastal linear regression rate have calculated. It shows an average of-2.63 $\mathrm{m}$ /year from the year of (1971-2013) (Table.2). The rate came in terms of negative value shows the whole stretch was under the influence of erosion. The classification done as very high, High and Moderate Erosion or Accretion the Figure (4) denotes the changes.

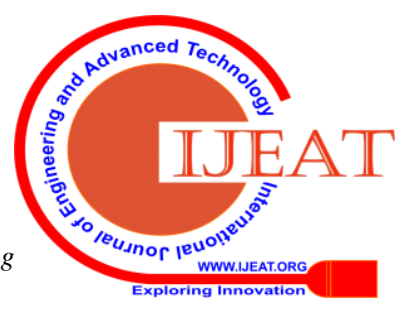



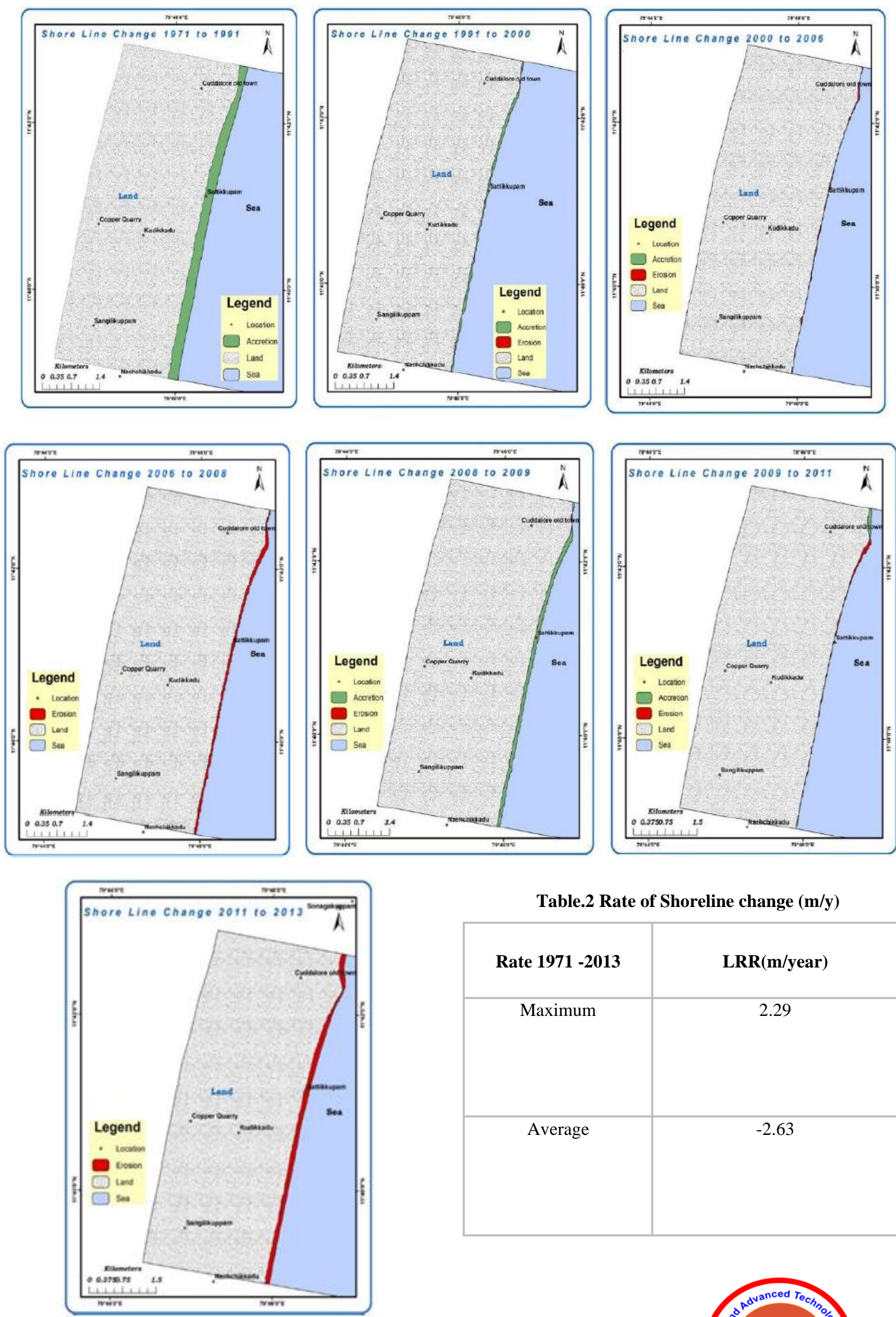

Table.2 Rate of Shoreline change $(\mathrm{m} / \mathrm{y})$

\begin{tabular}{|c|c|}
\hline Rate 1971 -2013 & LRR(m/year) \\
\hline Maximum & 2.29 \\
\hline Average & \\
\hline & -2.63 \\
\hline
\end{tabular}

Figures.3: Erosion and Deposition 1971-2013 
Remote Sensing and GIS Application for Shoreline Change Measurement in South East Coastal region of Tamil Nadu, India

\begin{tabular}{|l|l|} 
Minimum & -4.01 \\
& \\
\hline
\end{tabular}
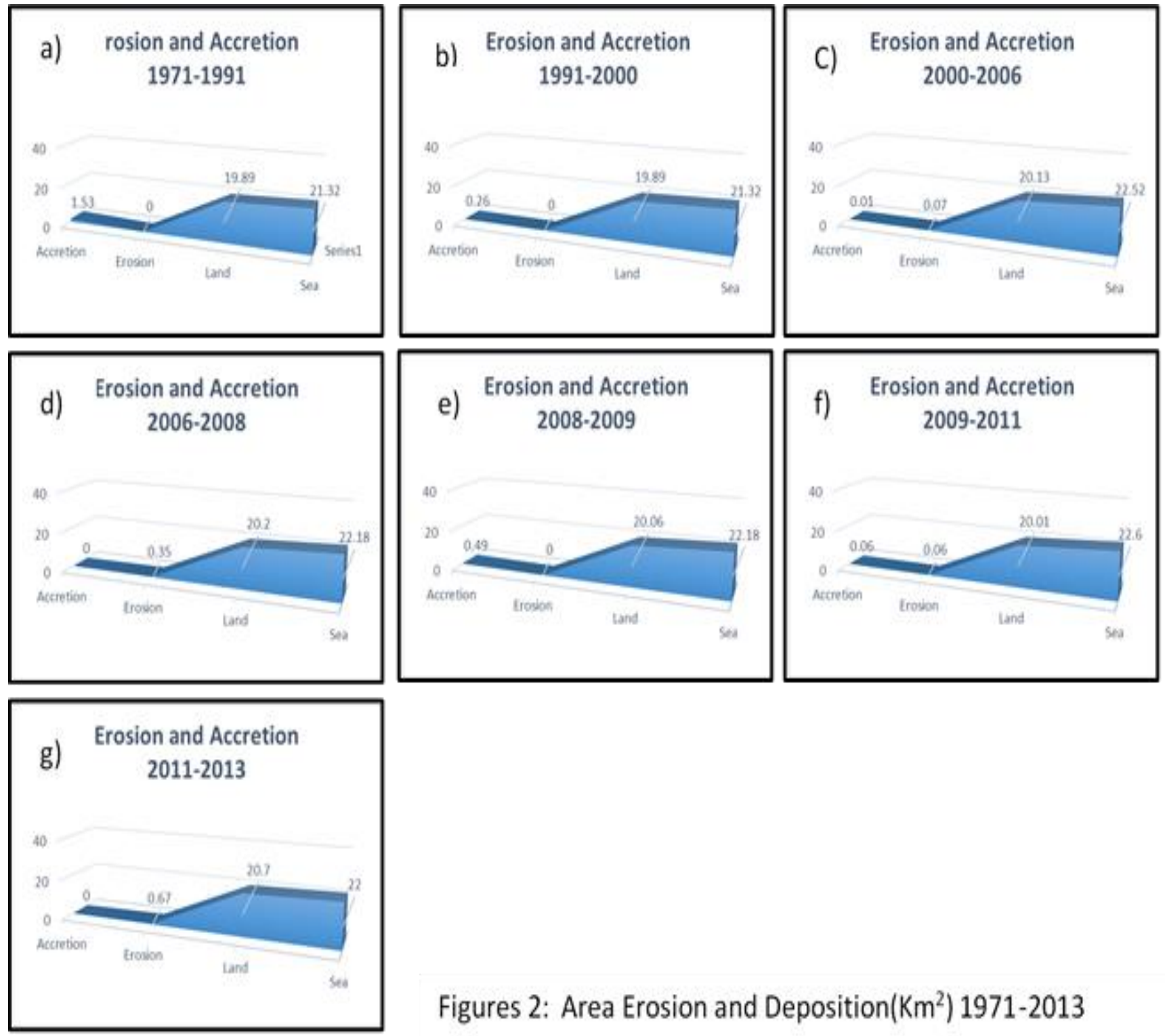

Figures 2: Area Erosion and Deposition $\left(\mathrm{Km}^{2}\right)$ 1971-2013

\section{CONCLUSION}

This study highlights the application of remote sensing and GIS to identify the changes in coastal zone. The datas from the satellite imageries that took before 2004 Tsunami and after, displays drastic changes in shoreline. The changes of shorelines in time interval shown in Fig.3. The Percentage of changes is also graphically plotted in Fig (5). The study concluded that this area was been under moderate accretion over past, up to the year 2000. But minor erosional changes initiated from the beginning of the 2006 and at the end of the study period it Reaches unnatural during 2013. The linear regression rate shows an average change of 2.63/year. The negative value of LRR shows that the whole coastal stretch of $9.3 \mathrm{~km}$ from cuddalore old town to Nachchikkadu was under siviour threat of erosion. The

major reason was the natural actions such as wave, wind, tidal actions, those prompted after catastrophic event Tsunami. Through the ground truthing survey the anthropogenic activities is also found increased during these days because of the availability of sea resources. As it reason like construction of artificial structures increases, River water regulatory works, and other urbanization pretend the zone as erodable in future. In such a condition beach nourishment activities are a possible remedy that could able to prevent such erosion.

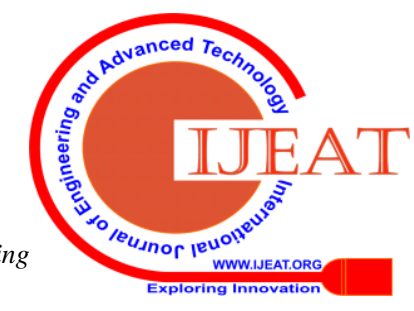




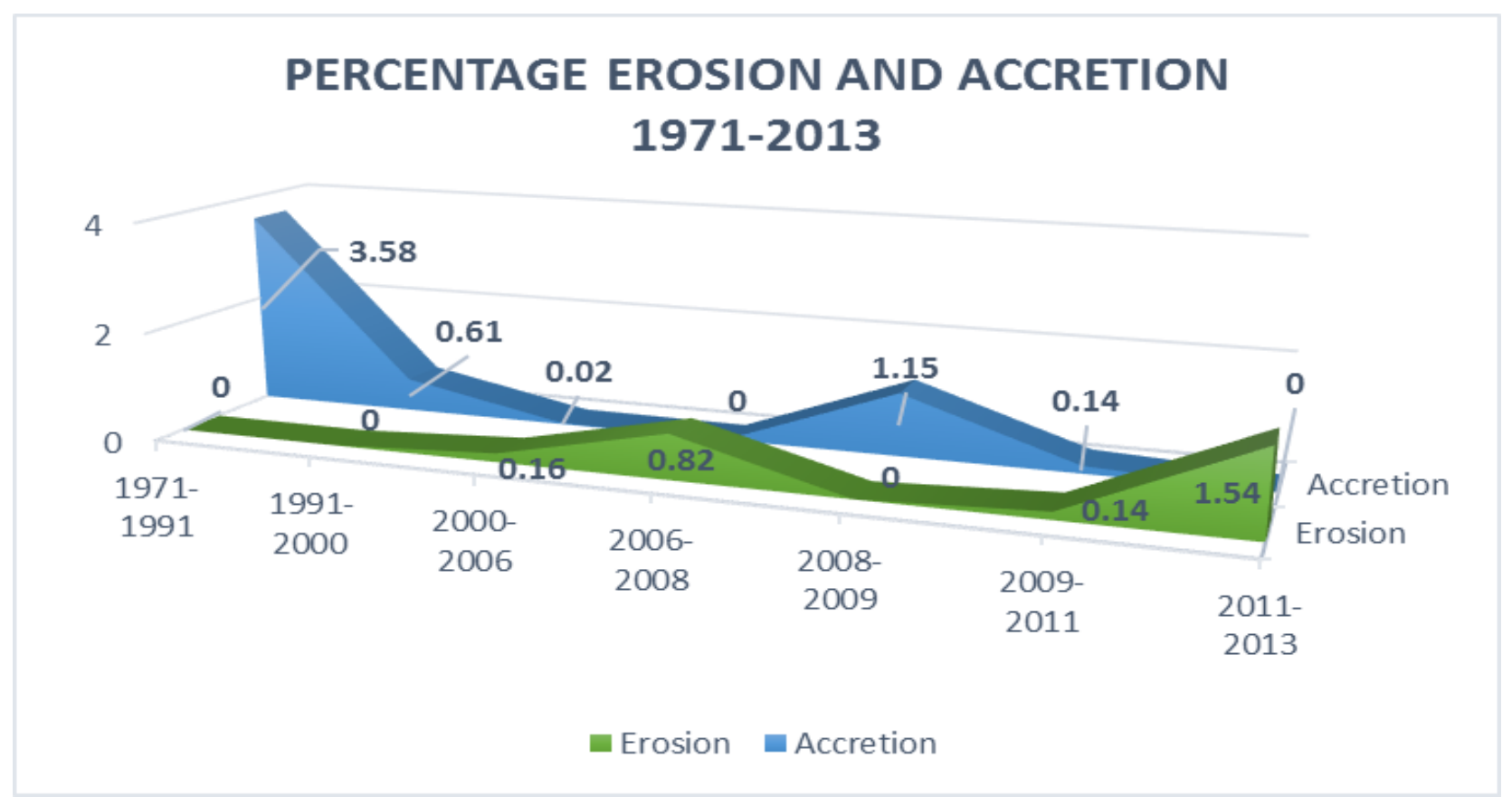

Figures.5: Percentage change 1971-2013

\section{REFERENCES}

1. Anirban Mukhopadhyay1,Sandip Mukherjee, Samadrita Mukherjee , Subhajit Ghosh, Sugata Hazra1 and Debasish Mitra (2012) Automatic shoreline detection and future prediction: A case study on Puri Coast, Bay of Bengal, India, European Journal of Remote Sensing - 2012, 45: 201-213

2. Ateeth,Shetty,Jayappa.K.S,.Mitra.D, Shoreline Change Analysis of Mangalore Coast and Morphometric Analysis of Netravathi-Gurupur and Mulky-Pavanje Spits,2015,Aquatic Procedia

3. Balasaraswathi, Srinivasalu S.,2016 Change detection analysis of coastal zone features in Cuddalore District, Tamilnadu using Remote sensing and GIS techniques, IOSR Journal of Applied Geology and Geophysics ISSN: 2321-0990, p-ISSN: 2321-0982,Volume 4.

4. Bouchahma M, Wanglin Y, Ouessar M (2012) Island coastline change detection based on image processing and remote sensing. Comput Inform Sci 5(3):27-36

5. Kumaravel.S, Ramkumar.T, Gurunanam.B, Suresh.M, Quantitative estimation of shoreline changes using remote sensing and GIS: A case study in the parts of Cuddalore district, East coast of Tamil Nadu, India, International Journal Of Environmental Sciences Volume 2, No 4, 2012.

6. Kumaravel.S, Ramkumar.T, Gurunanam.B, Suresh.M,,Dharanirajan.k , An Application of Remote Sensing and GIS Based Shoreline Change Studies - A Case Study in the Cuddalore District, East Coast of Tamilnadu, South India, International Journal of Innovative Technology and Exploring Engineering (IJITEE)ISSN: 2278-3075, Volume-2, Issue-4, March 2013

7. Kwarteng A (2009) Remote sensing monitoring of coastal erosion in Al Batinah, Sultanate of Oman. In: Coastal erosion and groundwater, proceeding of a workshop on coastal erosion along $\mathrm{Al}$ Batinah, Sultanate of Oman, pp 45-54.

8. Lee J, Jurkevich I. (1990) - Coastline detection and tracing in SAR images. IEEE Transactions in Geosciences and Remote Sensing, 28: 662-668. International Journal of Engineering Science and Computing

9. Majed Bouchahma \& Wanglin Yan (2013) Monitoring shoreline change on Djerba Island using GIS and multi-temporal satellite data. Arab J Geosci (2014) 7:3705-3713

10. Mageswaran T, Ram Mohan v. Chenthamil selvan S ,Arumugam T Tune Usha, and Kankara R.S . Assessment of Shoreline changes along Nagapattinam Coast using Geospatial techniques, international journal of geomatics and geosciences volume 5, no 4, 2015.

11. Sheeja P.S, Ajay Gokul A.J .,2016 Application of Digital Shoreline Analysis System in Coastal Erosion International Journal of Engineering Science and Computing, IJESC Volume 6 Issue No. 6
12. Sheik Mujabar, Chandrasekar, A Shoreline Change Analysis Along the Coast Between Kanyakumari and Tuticorin, India, Using Digital Shoreline Analysis System, Geo-spatial Information Science 14(4):282-293 ,Volume 14, Issue 4,

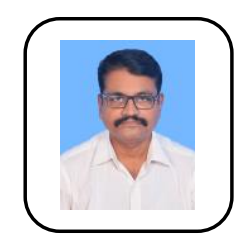

\section{AUTHORS PROFILE}

Dr. B. Gurugnanam, is a Professor of Geology in Center for Applied Geology, The Gandhigram Rural Institute - Deemed to be University. He has graduated in B.Sc., Geology and M.Sc., Applied Geology from Bharathidasan University. He did M.Phil., in Geology from University of Madras and

M.Tech., in Remote sensing from Bharathidasan

University. He did Ph.D., in Geospatial Technology application in water resources and specialised in Water, Disaster and Climate Change.

He has 24 years of experience. 